\title{
線形多自由度系の物理的パラメターの直接推定 \\ 可変振り子センサを用いた既存木造住宅の動特性同定法 \\ DIRECT ESTIMATION OF PHYSICAL DYNAMICAL PARAMETERS OF LINEAR MULTI DEGREE OF FREEDOM STRUCTURE
}

Identification of dynamic characteristics of existing wooden structure using variable pendulum sensor

古川忠稔*

\section{Tadatoshi FURUKAWA}

\begin{abstract}
This paper introduces a new structural identification technique using Variable Pendulum Sensor (VPS) for seismic evaluation of existing wooden house. Shifting the swinging cycle of the pendulum duplicates the equations of motion of the structural system including VPS, and makes it possible to directly estimate physical dynamical parameters such as mass, stiffness, and damping coefficient of the structure. To evaluate the performance of VPS, a series of numerical analyses are conducted. Result of the analysis shows that VPS can successfully estimate the physical dynamical parameters of multi degree of freedom structural system.
\end{abstract}

Keywords : Structural Identification, Wooden house, Physical parameters, Variable pendulum sensor, Prediction error method 構造同定，木造住宅，物理的パラメター，可変振り子センサ，予測誤差法

\section{1. はじめに}

地震時の建築物倒壊は, 死傷者発生の最大要因であるだけでなく 種々の被害拡大要因となる。そこで, 兵庫県南部地震において甚大 な被害が生じた戸建木造住宅の耐震化を促進するため, 既存不適格 となる木造住宅の耐震診断と補強が強く望まれている。木造住宅の 耐震診断では，通常は目視検査と設計図面に基づいて一般診断法に より現状の耐震性が評価される。その結果耐震性能が不十分と見な された場合には, 補強設計の為に一部破壊を伴う精密診断が行われ, 補強方針の決定や補強設計が行われる。

しかし建設時から長期間が経過した既存木造住宅では，経年変化 や劣化により, 建設時点から特性が変動している可能性がある。ま た, 建物各層の剛性や質量は非構造部材の影響などの不確定要素が あり，積載荷重も実態と対応しているとは限らない。これらを評価 に取り込み，定量的に評価することは現行の耐震診断法ではかなり 難しいと考えられる。そこで, 既存木造住宅の現時点の特性や補強 効果の評価の為に, 微動観測や起振器を用いた振動実験が行われる ことがある 1) 3)。その場合, 通常得られるのは各次モードの固有周 期や減衰定数, モード形といったモードパラメターである。しかし, 地震動により構造物が被災するかどうかの判断は, 最大層間変形な ごの尺度であり，これを推定するにはモードパラメターだけでは十 分とはいえない。さらに, 他の構造形式と異なり屋根部に大きな質 量を持つ木造住宅では, 建物に作用する外力を想定するためにも質 量分布を精度良く推定することが重要である。したがって, 既存木 造住宅の現状の耐震性を評価し，これに基づいて耐震診断や補強設 計を行うためには, 建物各層の層剛性や質量といった物理的パラメ
ターを精度良く推定することが重要となってくる。例えば，建物各 層の質量が直接推定可能であれば，一般診断法・精密診断法におい て必要耐力の算定根拠となる固定荷重と積載荷重の和について建物 の現状を反映させることが可能となる。また，加振器による振動応 答レベルという制約はあるものの，建物各層の剛性和や偏心率を推 定できれば，精密診断時に算定される壁基準剛性值の総和や，建物 各壁面の壁基準剛性から算定される偏心率について，建物の実情を 反映できると考えられる。

これまでにも，曾根ら ${ }^{4)}$, 中村ら 5), 川瀬ら 6)により建築物の物理 的パラメターの推定方法が提案されている。このうち前 2 者はいず れも層質量を既知として物理的パラメターを推定している。これに 対し川瀬らは対象建物に既知の付加質量を加え, 固有周期の変化か ら質量を含む物理的パラメターの推定手法を提案し，既存建物の物 理的パラメター推定を行っている。さらに建設過程で建物重量が増 加することを利用し, 同手法を用いて微動観測結果から免震層のせ 几断剛性推定も行っている7)。しかし，構造物の固有周期を変化さ せるには相当量の質量付加が必要であり，かつ付加質量の相対的な 大きさが推定精度に直接影響することから，川瀬らの場合では建物 の約 $1 \%$ の質量を付加している。すなわち同手法を一般的な戸建木 造住宅（重量 20〜30t）に適用するためには，200～300kg 程度の重 りを載荷する必要がある。この重量を木造住宅に載荷することは不 可能ではないが，載荷位置の制約や実験手間の問題を考えると改良 の余地があると考えられる。

これらの現状を踏まえ，著者らは質量，剛性および粘性減衰係数 が既知で，かつ剛性を変化できる 1 自由度系からなる特殊なセンサ

\footnotetext{
本論文の一部は, 日本建築学会大会学術講演梗概集 (九州), 構造 C-1 (2007.8) に発表している。

* 名古屋大学大学院環境学研究科都市環境学専攻 Assoc. Prof., Dept. of Environmental Eng. and Architecture, Graduate School of 准教授・博士 (工学)

Environmental Studies, Nagoya Univ., Dr. Eng.
} 
(以後可変振り子センサと呼ぶ) を建物内に設置し, 剛性変化前後 における建物応答と可変振り子センサの応答から対象建物の質量を 含めた物理的パラメター推定手法を考案した ${ }^{8-9)}$ 。建物モデルとして 線形 1 層モデルと同 2 層せん断型モデルを用いた基礎的なシミュレ ーションを通じ, 建物質量の概ね $1 / 1000$ 程度の振り子質量を持つ可 変振り子センサを使用すれば, 推定誤差 $10 \%$ 以内で質量, 剛性およ び粘性減衰係数を同時推定可能であることが確かめられている。提 案する可変振り子センサを実現させる機構には種々のものが考えら れるが, 対象が木造建物の場合, 建物質量の $1 / 1000$ 程度の振り子質 量は高々数十 $\mathrm{kg}$ 程度と想定されるので, 1 方向レール上に質量体を 載せ，質量体の移動方向両端からバネで支持して復元力を与え，バ ネを付け替えることで固有周期を変化させる機構で十分実現可能と 考えられる。

本論文では，可変振り子センサを用いて線形多自由度系の物理的 パラメターを直接推定する原理を示すと共に，2 階建程度の実木造 建物の動特性推定に本センサを用いることを想定し，2 層せん断型 モデルを対象とする同定シミュレーション方法とその結果を詳細に 報告するとともに，1 層ねじれモデルの物理的パラメター推定に対 しても可変振り子センサが有効であることを示寸。

\section{2. 同定の原理とアルゴリズム}

2. 1 同定の原理

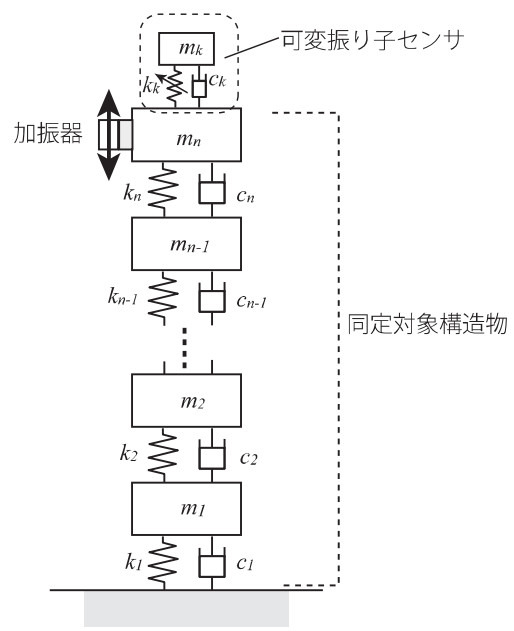

図 1 可変振り子センサが付加された多自由度構造物モデル

図 1 に示寸多自由度構造物モデルの端部に, 可変振り子センサを 付加した場合の運動方程式は

\section{$\boldsymbol{M} \ddot{\boldsymbol{x}}+\boldsymbol{C} \dot{\boldsymbol{x}}+\boldsymbol{K} \boldsymbol{x}=\boldsymbol{f}$}

ここに, $\boldsymbol{x}$ は図 1 に示す固定点を基準とする各質点移動量の相対変 位ベクトルであり

$$
\boldsymbol{x}=\left[\begin{array}{lllll}
x_{1} & x_{2} & \cdots & x_{n} & x_{k}
\end{array}\right]^{T}
$$

とする。 $f(t)$ を加振器による加振力とすると, 図 1 では(1)式右辺の $\boldsymbol{f}$ は $n+1$ 行の列ベクトルであり下式となる。

$$
\boldsymbol{f}=\left[\begin{array}{llllll}
0 & 0 & \cdots & 0 & f(t) & 0
\end{array}\right]^{T}
$$

$\boldsymbol{M}, \boldsymbol{C}, \boldsymbol{K}$ はおのおの質量, 減衰, 剛性マトリクスであり, 図 1 の場合 (4)式となる。

$$
\begin{aligned}
\boldsymbol{M} & =\left[\begin{array}{ccccc}
m_{1} & 0 & \cdots & 0 & 0 \\
0 & m_{2} & \cdots & 0 & 0 \\
\vdots & \vdots & \ddots & \vdots & \vdots \\
0 & 0 & \cdots & m_{n} & 0 \\
0 & 0 & \cdots & 0 & m_{k}
\end{array}\right] \\
\boldsymbol{C} & =\left[\begin{array}{ccccc}
c_{1}+c_{2} & -c_{2} & \cdots & 0 & 0 \\
-c_{2} & c_{2}+c_{3} & \cdots & 0 & 0 \\
\vdots & \vdots & \ddots & \vdots & \vdots \\
0 & 0 & \cdots & c_{n}+c_{k} & -c_{k} \\
0 & 0 & \cdots & -c_{k} & c_{k}
\end{array}\right] \\
\boldsymbol{K} & =\left[\begin{array}{ccccc}
k_{1}+k_{2} & -k_{2} & \cdots & 0 & 0 \\
-k_{2} & k_{2}+k_{3} & \cdots & 0 & 0 \\
\vdots & \vdots & \ddots & \vdots & \vdots \\
0 & 0 & \cdots & k_{n}+k_{k} & -k_{k} \\
0 & 0 & \cdots & -k_{k} & k_{k}
\end{array}\right]
\end{aligned}
$$

(4)式中, 要素の添え字が $k$ のものは付加 1 自由度系のもので既知 量であるから，マトリクスに含まれる物理パラメターのうち未知パ ラメターの合計は $3 n$ 個となる。

ここで，まず可変振り子センサの剛性を $k_{k}=k_{k 1}$ に設定し，加振実 験等により $i$ 次モードの固有円振動数 $\omega^{(i)}$ と減衰定数 $h^{(i)}$ が各 $r$ 個 (最大值 $n+1$ ) 求められたとする。すると, 系の固有值 $\lambda^{(i)}$ と $\omega^{(i)}$ 及 び $h^{(i)}$ の関係

$$
\lambda^{(i)}=-h^{(i)} \omega^{(i)} \pm i \omega^{(i)} \sqrt{1-\left(h^{(i)}\right)^{2}}
$$

から, $r$ 組の共役な複素固有值 $\lambda^{(i)}$ が決定できる。この值を(6)式に示 寸固有值の特性方程式

$$
\left|\boldsymbol{M} \lambda^{2}+\boldsymbol{C} \lambda+\boldsymbol{K}_{k_{k}=k_{k 1}}\right|=0
$$

に代入すると $r$ 組の式を得る。(6)式の值は複素数であることから， 実部と虚部をそれぞれ別々に考えて, 式の数は実際には $2 r$ 個となる。 前述したように $r$ の最大值は $n+1$ であるから, 式数は最大で $2(n+1)$ 個となり, 自由度 $n$ が 3 以上なら $3 n>2(n+1)$ と常に未知パラメター 数が式数を上回るため,未知パラメターを決定することはできない。

そこで可変振り子センサの剛性を $k_{k}=k_{k 2}$ と変更し, 新たな加振実 験を追加して $s$ 個 $(s$ の最大值も $n+1)$ の $j$ 次モードの固有円振動数 $\omega^{(j)}$ 及び減衰定数 $h^{(j)}$ が得られれば，(5)式から $s$ 組の共役な複素固 有值 $\lambda^{(j)}$ が決定できる。よって，新たな固有值の特性方程式

$$
\left|\boldsymbol{M} \lambda^{2}+\boldsymbol{C} \lambda+\boldsymbol{K}_{k_{k}=k_{k 2}}\right|=0
$$

を $s$ 組得ることができる。この様にして固有值の特性方程式の数を 未知パラメターの合計数より増や寸ことで物理パラメターである $m$, $k, c$ を決定できるようになる。

対象構造物の自由度が高く，同定すべき未知数がより多い場合に は，センサの剛性をさらに変更するか，あるいはセンサを複数個取 り付け，これらの特性を順次変更した加振実験を追加することで必 要なだけ固有值の特性方程式を得ることができる。

\section{2 同定計算法}

同定の原理の項に示したように，可変振り子センサの剛性を変化 させ複数回の加振実験を実施して周波数応答を求め, この結果から 各次モードの固有周期と減衰定数を求めて特性方程式を解くことで 同定計算を行うことができる。しかし，本論文では線形システムが 時間領域と周波数領域で一対一対応であることを踏まえ，構造物モ デルを多入力多出力系の扱いが容易な時間領域での状態空間モデル 
で表現し，予測誤差法を適用して未知パラメターの推定を行う 10)。 なおこの時間領域での状態空間モデルを用いた同定手法は, 復元力 が非線形の場合にも拡張できるため, 大振幅時の木造建物の復元力 特性や減衰特性の非線形性を考慮した同定計算を行うことも将来的 に可能な手法である ${ }^{11-12)}$ 。時間領域で前述した周波数領域の同定手 法と等価な同定計算を実施するためには, 可変振り子センサの剛性 変化前後を示す $2 つ$ 状態空間モデルを一つの状態空間モデルとし て結合する必要がある。そこで図 1 の構造物モデルを例に, 以下個々 の状態空間モデル作成とその結合, および同定計算法について述べ る。

可変振り子センサの剛性を $k_{k}=k_{k 1}$ とし, 状態量ベクトルを(8)式と する。

$$
{ }_{1} \boldsymbol{x}=\left[\begin{array}{lllllllll}
{ }_{1} x_{1} & \cdots & { }_{1} x_{n} & { }_{1} x_{k} & \vdots & { }_{1} \dot{x}_{1} & \cdots & { }_{1} \dot{x}_{n} & { }_{1} \dot{x}_{k}
\end{array}\right]^{T}
$$

ここで, 左下添え字は可変振り子センサの剛性が $k_{k 1}$ あることを示し, 右辺括弧内のベクトル要素につくドットは時間微分を示す。すなわ ち, 状態量は各質点の変位および速度としている。(1)〜(3)式より, 状態方程式は

$$
{ }_{1} \dot{x}={ }_{1} A_{c} \cdot{ }_{1} x+{ }_{1} B_{c} \cdot{ }_{1} u
$$

ここに, システム行列 ${ }_{1} \boldsymbol{A}_{c}$, 制御行列 ${ }_{1} \boldsymbol{B}_{c}$, 及び入力ベクトル ${ }_{1} \boldsymbol{u}$ は

$$
{ }_{1} \boldsymbol{A}_{c}=\left[\begin{array}{c:c}
\boldsymbol{0} & \boldsymbol{I} \\
\hdashline-\boldsymbol{M}^{-1} \boldsymbol{K}_{k_{k}=k_{k 1}} & -\boldsymbol{M}^{-1} \boldsymbol{C}
\end{array}\right],{ }_{1} \boldsymbol{B}_{c}=\left[\begin{array}{c}
\boldsymbol{0} \\
\hdashline \boldsymbol{M}^{-1}
\end{array}\right],{ }_{1} \boldsymbol{u}=\left[\begin{array}{c}
\boldsymbol{0} \\
\hdashline{ }_{1} \boldsymbol{f}
\end{array}\right]
$$

であり, 右添え字 $c$ は連続時間であることを示す。なお(10)式の各 マトリクス内の点線は, 点線で分割される各部分行列が分割に対応 する行列数であることを示す。

応答観測の条件に応じて(11)式で示寸観測方程式をたてる。

$$
{ }_{1} y={ }_{1} C_{c} \cdot{ }_{1} x
$$

ここで，例えば観測量ベクトル ${ }_{1} \boldsymbol{y}$ を

$$
{ }_{1} \boldsymbol{y}=\left[\begin{array}{l}
\text { 可変振り子センサと設置位置との相対変位 } \\
\text { 可変振り子センサの絶対加速度 }
\end{array}\right]
$$

とすると, 出力マトリクス ${ }_{1} \boldsymbol{C}_{c}$ は(12)式のような $2 \times 2(n+1)$ のマリ クスとなる。

$$
{ }_{1} \boldsymbol{C}_{c}=\left[\begin{array}{ccccc:ccccc}
0 & 0 & \cdots & -1 & 1 & 0 & 0 & \cdots & 0 & 0 \\
\hdashline 0 & 0 & \cdots & k_{k 1} / m_{k} & -k_{k 1} / m_{k} & 0 & 0 & \cdots & c_{k} / m_{k} & -c_{k} / m_{k}
\end{array}\right]
$$

次に, 可変振り子センサの剛性を $k_{k}=k_{k 2}$ に変更し, 同様な手順で 状態空間モデルを構築する。状態量は(8)式と同じ各質点変位と速度 とするが, 区別のため左下添え字を 2 とする。よって状態量べクト ルは(13)式となる。

$$
{ }_{2} \boldsymbol{x}=\left[\begin{array}{lllllllll}
{ }_{2} x_{1} & \cdots & { }_{2} x_{n} & { }_{2} x_{k} & \vdots & { }_{2} \dot{x}_{1} & \cdots & { }_{2} \dot{x}_{n} & { }_{2} \dot{x}_{k}
\end{array}\right]^{T}
$$

このとき, 状態方程式は

$$
\begin{aligned}
& { }_{2} \dot{\boldsymbol{x}}={ }_{2} \boldsymbol{A}_{c} \cdot{ }_{2} \boldsymbol{x}+{ }_{2} \boldsymbol{B}_{c} \cdot{ }_{2} \boldsymbol{u} \\
& \text { ここに, }
\end{aligned}
$$

$$
{ }_{2} \boldsymbol{A}_{c}=\left[\begin{array}{c:c}
\boldsymbol{0} & \boldsymbol{I} \\
\hdashline-\boldsymbol{M}^{-1} \boldsymbol{K}_{k_{k}=k_{k 2}} & -\boldsymbol{M}^{-1} \boldsymbol{C}
\end{array}\right],{ }_{2} \boldsymbol{B}_{c}=\left[\begin{array}{c}
\boldsymbol{0} \\
\hdashline \boldsymbol{M}^{-1}
\end{array}\right],{ }_{2} \boldsymbol{u}=\left[\begin{array}{c}
\boldsymbol{0} \\
\hdashline{ }_{2} \boldsymbol{f}
\end{array}\right]
$$

観測方程式は(16)式とする。

$$
{ }_{2} \boldsymbol{y}={ }_{2} \boldsymbol{C}_{c \cdot 2} \boldsymbol{x}
$$

可変振り子センサの剛性が $k_{k}=k_{k 1}$ のときと同じく, 観測量を可変 振り子センサと設置位置との相対変位, および振り子センサの応答 絶対加速度とすると, 出力マトリクス ${ }_{2} \boldsymbol{C}_{c}$ は(17)式となる。

$$
{ }_{2} \boldsymbol{C}_{c}=\left[\begin{array}{ccccc:ccccc}
0 & 0 & \cdots & -1 & 1 & \vdots & 0 & \cdots & 0 & 0 \\
\hdashline 0 & 0 & \cdots & k_{k 2} / m_{k} & -k_{k 2} / m_{k} & 0 & 0 & \cdots & c_{k} / m_{k} & -c_{k} / m_{k}
\end{array}\right]
$$

以上により可変振り子センサの剛性変化前後の状態空間モデルが 各々得られたので，(9)と(11)式で表現された変化前の状態空間モデ ルと, (14)と(16) 式で表現された変化後の状態空間モデルを結合し た新たな状態空間モデルを考える。

$$
\begin{aligned}
& { }_{t} \dot{x}={ }_{t} A_{c} \cdot{ }_{t} \boldsymbol{x}+{ }_{t} B_{c} \cdot{ }_{t} u \\
& { }_{t} \boldsymbol{y}={ }_{t} \boldsymbol{C}_{c} \cdot{ }_{t} \boldsymbol{x}
\end{aligned}
$$

ここに，左下添え字の $t$ は前述の二つの状態空間モデルの結合モ デルであることを示す。結合モデルの状態量ベクトルは(8) 式およ び(13)式での状態量ベクトルを縦に並べたものとし, 観測量べクト ルも同様に(11) 式および(16)式の観測量ベクトルを縦に並べ

$$
{ }_{t} x=\left[\begin{array}{l}
{ }_{1} x \\
{ }_{2} x
\end{array}\right],{ }_{t} y=\left[\begin{array}{l}
{ }_{1} y \\
{ }_{2} y
\end{array}\right]
$$

とする。このとき(18)式の状態空間モデル右辺の各マトリクスおよ びベクトルは(20)式で表される。

$$
\begin{aligned}
& { }_{t} \boldsymbol{A}_{c}=\left[\begin{array}{c:c}
{ }_{1} \boldsymbol{A}_{c} & \boldsymbol{0} \\
\hdashline \boldsymbol{0} & { }_{2} \boldsymbol{A}_{c}
\end{array}\right],{ }_{t} \boldsymbol{B}_{c}=\left[\begin{array}{c:c}
{ }_{1} \boldsymbol{B}_{c} & \boldsymbol{0} \\
\hdashline \boldsymbol{0} & { }_{2} \boldsymbol{B}_{c}
\end{array}\right],{ }_{t} \boldsymbol{u}=\left[\begin{array}{c}
{ }_{1} \boldsymbol{u} \\
\hdashline{ }_{2} \boldsymbol{u}
\end{array}\right], \\
& { }_{t} \boldsymbol{C}_{c}=\left[\begin{array}{c:c}
{ }_{1} \boldsymbol{C}_{c} & \boldsymbol{0} \\
\hdashline \boldsymbol{0} & { }_{2} \boldsymbol{C}_{c}
\end{array}\right]
\end{aligned}
$$

同定計算は(18)式の状態空間モデルを用いて行う。(18)式のモデル をデータサンプリング周期で離散化し, 状態ノイズ $\boldsymbol{\Gamma} \boldsymbol{v}_{k}$ と観測ノイ ズ $\boldsymbol{v}_{k}$ を考慮すると, 離散時間における状態量ベクトルの推定值 $\hat{\boldsymbol{x}}$ と 観測值ベクトル $y_{t}$ の関係は, (21)式に示寸イノベーション型の離散 状態空間モデルとなる。

$$
\begin{aligned}
& \hat{\boldsymbol{x}}_{t+1}{ }_{t} \boldsymbol{A}_{d} \cdot \hat{\boldsymbol{x}}_{t}+{ }_{t} \boldsymbol{B}_{d} \cdot{ }_{t} \boldsymbol{u}_{t}+\boldsymbol{\Gamma} \cdot \boldsymbol{v}_{t} \\
& \boldsymbol{y}_{t}={ }_{t} \boldsymbol{C}_{d} \cdot \hat{\boldsymbol{x}}_{t}+\boldsymbol{v}_{t}
\end{aligned}
$$

同定計算においては, (21)式より得られる観測量の一段階先予測 值 $\hat{\boldsymbol{y}}_{t+1}$ は(22)式となる。

$$
\hat{\boldsymbol{y}}_{t+1}={ }_{t} \boldsymbol{C}_{d}\left[\left({ }_{t} \boldsymbol{A}_{d}-\boldsymbol{\Gamma} \cdot{ }_{t} \boldsymbol{C}_{d}\right) \hat{\boldsymbol{x}}_{\boldsymbol{t}}+\boldsymbol{\Gamma} \cdot \boldsymbol{y}_{\boldsymbol{t}}+{ }_{t} \boldsymbol{B}_{d} \cdot{ }_{t} \boldsymbol{u}_{t}\right]
$$

この一段階先予測值と観測值の差で定義される予測誤差の二乗和を, 非線形最小二乗法の逐次計算を用いて最小化するパラメターを見い だすことでモデルのパラメターを推定する。同手法の詳細について は参考文献 14)を参照されたい。

\section{2 層せん型モデルによる同定精度の検証}

参考文献 15 に示されている木造住宅モデルを参考に, 図 2 に示寸 2 層せん断型構造物モデルを作成した。参考文献の木造住宅モデル は各階床面積が $57.97 \mathrm{~m}^{2}$, 総二階建てプランの比較的小規模な木造 住宅である。モデル化に際し, 各層質量は参考文献の記載値をその まま使用し, 各層剛性は壁倍率が真のせん断変形角 $1 / 150 \mathrm{rad}$ 時の 
耐力を含めて導かれていることから各層 $\mathrm{Y}$ 方向の個々の壁剛性を算 定し, これを合算して求めたものを若干調整して設定した。各層の 粘性減衰係数は 1 次モードの減衰定数が $5 \%$ となるように, 剛性比 例を仮定して設定した。作成した対象モデル各層の物理的パラメタ 一は表 1 に示寸とおりである。この対象モデルに対し, 可変振り子 センサを設置して加振実験を行った場合の同定精度を検証する。対 象モデルのモード特性は表 2 に示寸とおりである。

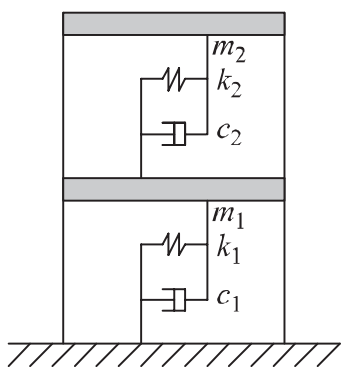

図 2 対象モデル

表 1 対象モデル各層の物理的パラメター

\begin{tabular}{c|c|c|c}
\hline 層 & 質量 $[\mathrm{t}]$ & 剛性 $[\mathrm{kN} / \mathrm{m}]$ & 減衰係数 $[\mathrm{kN} \cdot \mathrm{s} / \mathrm{m}]$ \\
\hline 1 & $m_{1}=14.03$ & $k_{1}=3684.9$ & $c_{1}=30.79$ \\
\hline 2 & $m_{2}=8.22$ & $k_{2}=3962.7$ & $c_{2}=33.11$ \\
\hline
\end{tabular}

表 2 対象モデルのモード特性值

\begin{tabular}{c|c|c}
\hline モード & 固有周期 $[\mathrm{s}]$ & 減衰定数 \\
\hline 1 次 & 0.525 & 0.050 \\
\hline 2 次 & 0.211 & 0.124 \\
\hline
\end{tabular}

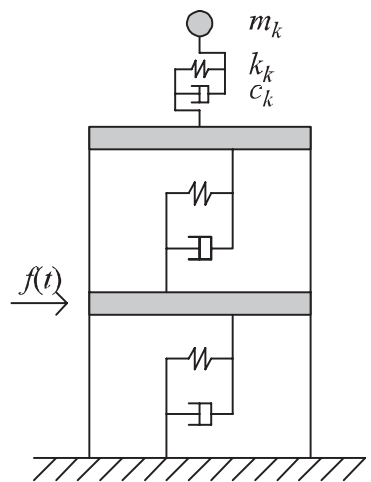

(1)Type-A

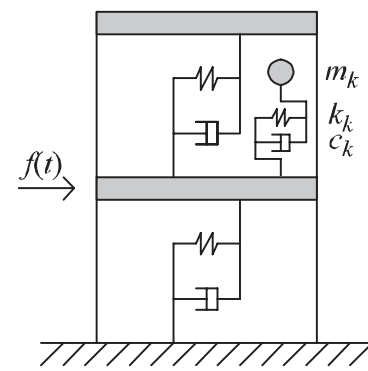

(2) Type-B
図 3 可変振り子センサ設置位置および加振位置

可変振り子センサの設置位置は, 図 3 (a),(b)に示すように, 2 層目 又は 1 層目とし，加振器による加振はモデル 1 層目に可動質量反力 式の加振器を建物床面に設置することを想定し，いずれの場合も 1 層目とする。

したがって図 3 (a)に対応する運動方程式の質量, 減衰, 剛性マト リクスは(4)式において $n=2$ としたものとなり，同 (b)に対応する運 動方程式の各マトリクスは式(23)となる。

$$
\begin{aligned}
\boldsymbol{M} & =\left[\begin{array}{ccc}
m_{1} & 0 & 0 \\
0 & m_{2} & 0 \\
0 & 0 & m_{k}
\end{array}\right], \boldsymbol{C}=\left[\begin{array}{ccc}
c_{1}+c_{2}+c_{k} & -c_{2} & -c_{k} \\
-c_{2} & c_{2} & 0 \\
-c_{k} & 0 & c_{k}
\end{array}\right] \\
\boldsymbol{K} & =\left[\begin{array}{ccc}
k_{1}+k_{2}+k_{k} & -k_{2} & -k_{k} \\
-k_{2} & k_{2} & 0 \\
-k_{k} & 0 & k_{k}
\end{array}\right]
\end{aligned}
$$

可変振り子センサのパラメターは, 質量は対象モデル総質量の約 $1 / 1000$ にあたる $25 \mathrm{~kg}$ とし, 図 3 に示す可変振り子センサの質量 $m_{k}$, 剛性 $k_{k}$, および粘性減衰係数 $c_{k}$ で定まるセンサのみの 1 自由度 系の固有周期が，表 2 に示寸対象モデルの 1 次固有周期(0.525 秒), 2 次固有周期(0.211 秒), および 2 次周期の半分（0.106 秒）の 3 つ となるように可変振り子センサの基準剛性 $k_{k}$ を設定した。この基準 剛性に対応する固有周期を以後規準固有周期 1st, 2nd, U2nd と呼ぶ。 なお，センサの減衰定数は常に 0.02 と設定している。

観測データは入力を加振力, 出力はセンサの絶対加速度及びセン サとセンサ設置床との相対変位とする。なお, 加振力は振幅が $10 \mathrm{kN}$ で, 65 秒間で周期 1 秒から 0.2 秒まで変化する線形掃引波を用いた。

同定用の応答データは，剛性可変前後の可変振り子センサ固有周 期が上述の規準固有周期を中心に $\pm 5 \%$ の幅で変化させることとし， 1st，2nd，U2ndの 3 つの基準固有周期に対して各 2 ケース，全体で 6 ケースの時刻歴応答計算を行って作成する。本検討では，基準固 有周期ごとに得られる 2 つの応答観測データを(19)式中の ${ }_{t} \boldsymbol{y}$ によ り，加振力データは $(20)$ 式中 ${ }_{t} \boldsymbol{u}$ により各々結合して 3 つの基準固有 周期ごとの同定用データセットを作成し，この同定用データセット に対し 2 章で記述した(18)式の状態空間モデルを用い，予測誤差法 により同定計算を実施する。

前述したように, 予測誤差法は実験データとモデル出力の応答の 誤差 (予測誤差) を最小化する同定パラメターを逐次計算により求 めて推定パラメターを決定する推定法であり，計算上，同定パラメ ターの初期值が必要となるとともに，同定精度が同定パラメター初 期值に依存する。そこで，この同定精度の初期值依存性を小さくす るため以下の手順により同定計算を実施する。まず，1st，2nd，U2nd の 3 つの同定用データセットごとに, 表 1 に示す 6 つの同定パラメ ター初期值を真值の $0.5 \sim 1.5$ 倍の範囲で正規分布となるようランダ ムに 100 組生成する。次に同一の同定用データセットを用いて，生 成した 100 組のパラメター初期值を使って 100 回の異なる同定計算 を実施する。同定結果の評価はこれら 100 回の同定計算結果から, 同定パラメターの中央值と，すべての同定パラメターが真值の $\pm 5 \%$ の範囲に収束する収束確率で評価する。なお，同定計算時には誤差 混入による精度低下を考慮し，信号とノイズの分散比(Signal to Noise Ratio; SNR)で定義されるホワイトノイズを加振力および応 答量の観測データに付加した。

同定計算結果の一覧を表 3 および表 4 に示す。同表より， Type-A,B とも同定パラメターの推定精度は概放良好であり，可変 振り子センサの基準固有周期は対象建物の 2 次固有周期あるいはそ れより短い周期に設定すると推定精度，収束確率とも概ね高くなる こと, さらにノイズの SNR が $1 \%$ 以下であれば，推定誤差は最大 $5 \%$, 平均 $1 \%$ 以内の精度で同定が可能であることが明らかとなった。 センサ設置位置による差異はほとんどないが，推定精度の高い Case-2nd, U2nd の結果を比較すると，同定計算の収束確率の面で Type-B がやや優越することがわかる。なお，表 3 に示す Type-A の 
表 $3 \quad$ Type-A ( 2 層上にセンサー設置)

\begin{tabular}{|c|c|c|c|c|c|c|c|c|c|}
\hline \multirow{2}{*}{ Case } & \multirow{2}{*}{ SNR } & \multicolumn{7}{|c|}{ 中央值／真值 [\% ] } & \multirow{2}{*}{$\begin{array}{l}\text { 収束確率 } \\
( \pm 5 \% \text { 以内) }\end{array}$} \\
\hline & & $\mathrm{m}_{1}$ & $\mathrm{~m}_{2}$ & $\mathrm{k}_{1}$ & $\mathrm{k}_{2}$ & $\mathrm{c}_{1}$ & $\mathrm{c}_{2}$ & 平均 & \\
\hline \multirow{4}{*}{$1 \mathrm{st}$} & $0.01 \%$ & 100.07 & 100.04 & 100.15 & 99.49 & 99.92 & 100.11 & 99.96 & 0.82 \\
\hline & $0.10 \%$ & 103.59 & 96.46 & 99.98 & 98.60 & 100.83 & 95.95 & 99.24 & 0.69 \\
\hline & $1 \%$ & 99.72 & 98.41 & 99.14 & 98.72 & 100.16 & 102.16 & 99.72 & 0.71 \\
\hline & $5 \%$ & 147.86 & 46.57 & 99.94 & 63.31 & 102.61 & 67.81 & 88.02 & 0.00 \\
\hline \multirow{4}{*}{2 nd } & $0.01 \%$ & 100.15 & 99.72 & 99.91 & 99.95 & 100.09 & 100.01 & 99.97 & 1.00 \\
\hline & $0.10 \%$ & 99.53 & 100.57 & 100.17 & 99.83 & 99.91 & 99.75 & 99.96 & 1.00 \\
\hline & $1 \%$ & 99.38 & 101.87 & 100.89 & 100.38 & 100.86 & 99.39 & 100.46 & 1.00 \\
\hline & $5 \%$ & 99.38 & 101.87 & 100.89 & 100.38 & 100.86 & 99.39 & 100.46 & 1.00 \\
\hline \multirow{4}{*}{ U2nd } & $0.01 \%$ & 99.50 & 100.38 & 100.00 & 99.89 & 100.00 & 99.88 & 99.94 & 0.96 \\
\hline & $0.10 \%$ & 100.32 & 100.01 & 100.16 & 100.19 & 100.07 & 100.32 & 100.18 & 0.93 \\
\hline & $1 \%$ & 103.20 & 97.52 & 99.93 & 100.70 & 99.99 & 100.88 & 100.37 & 0.92 \\
\hline & $5 \%$ & 107.19 & 98.27 & 102.47 & 102.99 & 100.83 & 103.62 & 102.56 & 0.00 \\
\hline
\end{tabular}

表 4 Type-B ( 1 層上にセンサー設置 $)$

\begin{tabular}{|c|c|c|c|c|c|c|c|c|c|}
\hline \multirow{2}{*}{ Case } & \multirow{2}{*}{ SNR } & \multicolumn{7}{|c|}{ 中央值／真值 ［\%］ } & \multirow{2}{*}{$\begin{array}{l}\text { 収束確率 } \\
\text { (土5\%以内) }\end{array}$} \\
\hline & & $\mathrm{m}_{1}$ & $\mathrm{~m}_{2}$ & $\mathrm{k}_{1}$ & $\mathrm{k}_{2}$ & $\mathrm{c}_{1}$ & $\mathrm{c}_{2}$ & 平均 & \\
\hline \multirow{4}{*}{$1 \mathrm{st}$} & $0.01 \%$ & 99.27 & 100.26 & 99.81 & 99.77 & 99.54 & 101.01 & 99.94 & 1.00 \\
\hline & $0.10 \%$ & 100.65 & 99.57 & 100.03 & 100.52 & 100.87 & 97.44 & 99.85 & 0.99 \\
\hline & $1 \%$ & 102.24 & 100.67 & 101.28 & 101.09 & 97.66 & 118.12 & 103.51 & 0.00 \\
\hline & $5 \%$ & 96.47 & 104.18 & 100.77 & 97.02 & 86.73 & 142.73 & 104.65 & 0.00 \\
\hline \multirow{4}{*}{2 nd } & $0.01 \%$ & 100.01 & 100.02 & 100.04 & 99.99 & 100.01 & 100.00 & 100.01 & 1.00 \\
\hline & $0.10 \%$ & 100.03 & 99.68 & 99.88 & 99.76 & 99.89 & 99.79 & 99.84 & 1.00 \\
\hline & $1 \%$ & 101.52 & 99.97 & 100.63 & 100.61 & 101.83 & 97.27 & 100.31 & 1.00 \\
\hline & $5 \%$ & 101.31 & 102.84 & 102.40 & 102.39 & 97.59 & 103.19 & 101.62 & 1.00 \\
\hline \multirow{4}{*}{ U2nd } & $0.01 \%$ & 100.05 & 100.02 & 100.03 & 100.04 & 99.89 & 100.00 & 100.01 & 1.00 \\
\hline & $0.10 \%$ & 100.23 & 100.25 & 100.28 & 100.30 & 100.28 & 99.95 & 100.22 & 0.99 \\
\hline & $1 \%$ & 101.21 & 100.66 & 100.99 & 101.25 & 100.38 & 95.36 & 99.98 & 1.00 \\
\hline & $5 \%$ & 99.39 & 99.09 & 99.38 & 98.84 & 100.69 & 103.26 & 100.11 & 1.00 \\
\hline
\end{tabular}

基準固有周期 1 st の場合で SNR が $5 \%$ 時では, 同定精度が他に比較 して極端に低下しているが, これは対象モデル 2 層目の質量 $m_{2}$ と剛 性 $k_{2}$ の同定精度低下に起因している。ただし, どちらも真值の約 5 割から 6 割程度の值に推定されていることから，2 層目の質量剛性 比で規定される固有周期はある程度の精度で同定されたが，ノイズ の影響により物理的パラメターの大きさが精度よく同定されなかっ た為と考えられる。

以上より，実際の木造住宅へのセンサ取り付けの手間も考慮する と, 本センサを対象建物の 1 層上（実建物の 2 階床面）に設置し, 概衫 2 次固有周期以上の周期にセンサの基準固有周期を設定するこ とで高い同定精度が得られると考えられる。

\section{1 層ねじれモデルによる同定精度の検証}

図 4 に示寸衫じれを考慮した 1 層 2 方向せん断型構造物に対し, 可変振り子センサを設置して加振実験を行う場合の同定精度を検証 する。ここで用いる可変振り子センサは, 図 4(b)に示すような $x, y$ 方向に動く 1 質点 2 自由度系で, 質量, 各方向の剛性及び減衰係数 が既知であり, かつ剛性が可変であるものとする。センサの質量, 剛性および減衰係数は表 5 に示すとおりとする。
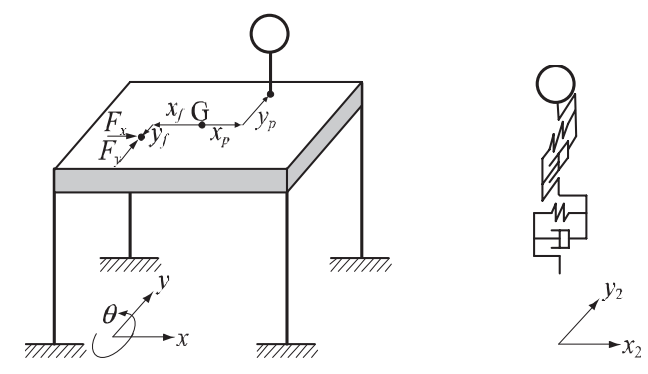

(a)同定モデル

(b) 可変振り子センサモデル

図4 1 層ねじれモデルおよび設置する可変振り子センサモデル

表 5 可変振り子センサの物理的パラメター

\begin{tabular}{c|c|c|c|c}
\hline 質量 & $x$ 方向剛性 1 & $x$ 方向剛性 2 & $y$ 方向剛性 1 & $y$ 方向剛性 2 \\
\multirow{4}{*}{$m_{2}$} & $k_{2 x}$ & $k_{3 x}$ & $k_{2 y}$ & $k_{3 y}$ \\
\cline { 2 - 5 } & $x$ 方向 & $x$ 方向 & $y$ 方向 & $y$ 方向 \\
& 減衰係数 1 & 減衰係数 2 & 減衰係数 1 & 減衰係数 2 \\
& $c_{2 x}$ & $c_{3 x}$ & $c_{2 x}$ & $c_{3 y}$ \\
\hline
\end{tabular}

図 4(a)の 1 層ねじれモデルについて, 対象構造物の重心点 $\mathrm{G}$ は既知 であると仮定し，この点の座標を $\left(x_{1}, y_{1}, \theta_{1}\right)$ とする。この重心点を基 
準とした相対座標系において $\left(x_{p}, y_{p}\right)$ の位置に可変振り子センサを設 置した場合, 基礎に対する可変振り子センサ位置は(24)式となる。

$$
\left(x_{1}-x_{p} \theta_{1}+x_{p}+x_{2}, \quad y_{1}+y_{p} \theta_{1}+y_{p}+y_{2}\right)
$$

基礎に対する可変振り子センサ質量の絶対加速度は, 回転項を無視 寸れば(25)式となる。

$$
\left(\ddot{x}_{1}+\ddot{x}_{2}, \quad \ddot{y}_{1}+\ddot{y}_{2}\right)
$$

力の釣合は(26)式で表される。

$$
\left\{\begin{array}{l}
m_{1} \ddot{x}_{1}+\sum_{i}\left\{k_{1 x i}\left(x_{1}-\ell_{1 y i} \theta_{1}\right)\right\}-k_{2 x} x_{2}=F_{x} \\
m_{2}\left(\ddot{x}_{1}+\ddot{x}_{2}\right)+k_{2 x} x_{2}=0 \\
m_{1} \ddot{y}_{1}+\sum_{i}\left\{k_{1 y i}\left(y_{1}+\ell_{1 x i} \theta_{1}\right)\right\}-k_{2 y} y_{2}=F_{y} \\
m_{2}\left(\ddot{y}_{1}+\ddot{y}_{2}\right)+k_{2 y} y_{2}=0 \\
I_{1} \ddot{\theta}_{1}-\sum_{i}\left\{k_{1 x i}\left(x_{1}-\ell_{1 y i} \theta_{1}\right) \ell_{1 y i}\right\} \\
\quad \quad+k_{2 x} x_{2} y_{p}+\sum_{i}\left\{k_{1 y i}\left(y_{1}+\ell_{1 x i} \theta_{1}\right) \ell_{1 x i}\right\}-k_{2 y} y_{2} x_{p}=F_{\theta}
\end{array}\right.
$$

ここで外力が 1 台の加振器によりもたらされ, 加振力 $F$ の向きが $x$ 軸から $\theta$ 回転した方向であるとすると, 加振器による $x, y$ 方向力およ びモーメントは

$$
F_{x}=F \cos \theta, F_{y}=F \sin \theta, F_{\theta}=F \ell
$$

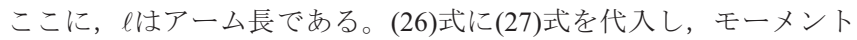
に関する式の両辺をとで割ると運動方程式は(28)式となる。

$\boldsymbol{M} \ddot{\boldsymbol{x}}+\boldsymbol{C} \dot{\boldsymbol{x}}+\boldsymbol{K} \boldsymbol{x}=\boldsymbol{F}$

(28)式の各マトリクスは,

$$
\begin{aligned}
& \boldsymbol{M}=\left[\begin{array}{lllll}
m_{1} & & & & \\
m_{2} & m_{2} & & & \\
& & m_{1} & & \\
& & m_{2} & m_{2} & \\
& & & & I_{1} / \ell
\end{array}\right] \\
& \boldsymbol{K}=\left[\begin{array}{ccccc}
K_{1 x} & -k_{2 x} & 0 & 0 & -K_{1 x} e_{1 y} \\
0 & k_{2 x} & 0 & 0 & 0 \\
0 & 0 & K_{1 y} & -k_{2 y} & K_{1 y} e_{1 x} \\
0 & 0 & 0 & k_{2 y} & 0 \\
-K_{1 x} e_{1 y} / \ell & k_{2 x} y_{p} / \ell & -K_{1 y} e_{1 x} / \ell & -k_{2 y} x_{p} / \ell & K_{1 \theta} / \ell
\end{array}\right] \\
& \boldsymbol{F}=\left[\begin{array}{lllll}
F \cos \theta & 0 & F \sin \theta & 0 & F
\end{array}\right]^{T} \\
& \boldsymbol{x}=\left[\begin{array}{lllll}
x_{1} & x_{2} & y_{1} & y_{2} & \theta_{1}
\end{array}\right]^{T}
\end{aligned}
$$

なお，減衰マトリクス $\boldsymbol{C}$ は剛性比例型で与えられるものとする。こ こで，(26)から(29)式中の各要素は以下の通りである。

\section{$m_{i}: i$ 層の質量}

$K_{1 x}=\sum_{i} k_{1 x i}: 1$ 層 $x$ 方向の剛性 $k_{1 x i}$ の和

$K_{1 y}=\sum_{i} k_{1 y i}: 1$ 層 $y$ 方向の剛性 $k_{1 y i}$ の和

$e_{1 x}=\sum_{i} k_{1 y i} \ell_{1 x i} / K_{1 y}: 1$ 層の偏心距離

$e_{1 y}=\sum_{i} k_{1 x i} \ell_{1 y i} / K_{1 x}: 1$ 層の偏心距離 $\ell_{1 x i}, \ell_{1 y i}: 1$ 層の剛性要素の $k_{1 x i}, k_{1 y i}$ 偏心距離

$K_{1 \theta}=\sum_{i} k_{1 x i} \cdot \ell^{2}{ }_{1 y i}+\sum_{i} k_{1 y i} \cdot \ell^{2}{ }_{1 x i}: 1$ 層重心まわりの放じれ剛性

$I=\int \rho r^{2} d V: 1$ 層の回転慣性

運動方程式は 2 層せん断モデルの例と同様に状態方程式に変換され る。観測量は付加される可変振り子センサの $x, y$ 方向に関する設置 位置との相対変位および絶対加速度とする。

参考文献 15 )に示されている前述の木造住宅モデルを参考に，1階 部分のみを取り出して一部を変形した 1 層構造物を考える。この構 造物の物理的パラメターを表 6 に示す。ここで粘性減衰係数は一次 モードの減衰定数を 0.05 とし, 剛性比例型として算定したものであ る。この対象モデルの各次モードの固有周期・固有振動数は表 7 の 通りとなる。

表 6 対象モデル各層の物理的パラメター

\begin{tabular}{c|c|c|c}
\hline$m_{1}$ & $10.03[\mathrm{t}]$ & $e_{1 x}$ & $-1.1858[\mathrm{~m}]$ \\
\hline$I_{1}$ & $103.13\left[\mathrm{t} \cdot \mathrm{m}^{2}\right]$ & $e_{1 y}$ & $0.98748[\mathrm{~m}]$ \\
\hline$K_{1 x}$ & $3725.7[\mathrm{kN} / \mathrm{m}]$ & $C_{1 x}$ & $24.544[\mathrm{kN} \cdot \mathrm{s} / \mathrm{m}]$ \\
\hline$K_{1 y}$ & $2615.9[\mathrm{kN} / \mathrm{m}]$ & $C_{1 y}$ & $17.233[\mathrm{kN} \cdot \mathrm{s} / \mathrm{m}]$ \\
\hline$K_{1 \theta}$ & $64908[\mathrm{kN} \cdot \mathrm{m} / \mathrm{rad}]$ & $C_{1 \theta}$ & $427.6[\mathrm{kN} \cdot \mathrm{m} \cdot \mathrm{s} / \mathrm{rad}]$ \\
\hline
\end{tabular}

表 7 対象モデルのモード特性值

\begin{tabular}{c|c|c|c}
\hline & 1 次 & 2 次 & 3 次 \\
\hline 固有周期 $[\mathrm{s}]$ & 0.4139 & 0.3410 & 0.2389 \\
\hline 固有振動 $[\mathrm{Hz}]$ & 2.416 & 2.932 & 4.186 \\
\hline
\end{tabular}

可変振り子センサのパラメターは，質量を 2 層せん断モデルと同 じく対象モデル総質量の約 $1 / 1000$ となる $10 \mathrm{~kg}$ とし, 重心を原点と して $\left(\begin{array}{ll}x_{p} & y_{p}\end{array}\right)=(2.275,-1.5925)[\mathrm{m}]$ の位置にセンサを設置する。 なお，(25)式に示したように本モデル化では，可変振り子センサ質 量の絶対加速度は, 設置床面の回転項を無視しているため, 可変振 り子センサ設置位置は建物重心点付近に設置する必要がある。

\begin{tabular}{|c|c|c|c|c|c|c|c|c|c|c|c|c|c|}
\hline \multirow{2}{*}{ SNR } & \multicolumn{6}{|c|}{ 中央値／真值 } & \multicolumn{5}{|l|}{$[\%]$} & \multicolumn{2}{|c|}{ 収束確率 } \\
\hline & $\mathrm{m}_{1}$ & $\mathrm{I}_{2}$ & $\mathrm{~K}_{1 \mathrm{x}}$ & $\mathrm{K}_{1 \mathrm{y}}$ & $\mathrm{K}_{1 \theta}$ & $\mathrm{e}_{1 \mathrm{x}}$ & $\mathrm{e}_{\mathrm{yy}}$ & $\mathrm{C}_{1 \mathrm{x}}$ & $\mathrm{C}_{1 \mathrm{y}}$ & $\mathrm{C}_{1 \theta}$ & 平均 & ( $\pm 5 \%$ 以内 $)$ & ( $\pm 1 \%$ 以内 $)$ \\
\hline $0.01 \%$ & 100.01 & 99.95 & 100.02 & 100.01 & 99.97 & 99.98 & 99.98 & 100.04 & 99.94 & 99.96 & 99.99 & 0.92 & 0.91 \\
\hline $0.10 \%$ & 99.99 & 100.03 & 100.00 & 100.00 & 100.02 & 99.98 & 99.99 & 99.97 & 100.19 & 100.00 & 100.02 & 0.95 & 0.95 \\
\hline $1 \%$ & 100.28 & 100.94 & 100.27 & 100.34 & 100.97 & 100.50 & 100.27 & 99.86 & 99.81 & 100.80 & 100.40 & 0.96 & 0.32 \\
\hline $5 \%$ & 100.92 & 100.29 & 100.85 & 100.89 & 100.26 & 98.92 & 99.85 & 100.90 & 100.75 & 99.92 & 100.35 & 0.97 & 0.00 \\
\hline
\end{tabular}

センサの規準固有周期は対象モデルの 3 次周期とし，同定時は可 変振り子センサの固有周期を, 規準固有周期を中心に土5\%の幅で変 化させる。なお，本検討では減衰係数を剛性比例で算出しているた め, 可変振り子センサの固有周期を変化させると結果としてセンサ の粘性減衰係数も若干変化することとなる。加振力としては, 振幅 が $10 \mathrm{kN}$ で 65 秒間に $1.5 \mathrm{~Hz}$ から $7.6 \mathrm{~Hz}$ まで指数関数的に変化する 掃引波

$$
Z(t)=10 \sin \left(2 \pi 1.5 e^{0.025 t} t\right)[k N], 0 \leq t \leq 65[\mathrm{sec}]
$$

を用いた。以上述べた条件において時刻歴応答計算を行い。得られ た入力と応答の両者の時刻歴波形にノイズとして適宜ランダム波を 付加したものを同定用データセットとして用い同定計算を行った。

表 8 1層ねじれモデルの同定計算結果 
同定パラメターの初期值は真值の $0.5 \sim 1.5$ 倍の範囲で正規分布 となるようにランダムに 1500 組生成し, これらすべての初期值を 用いて同定計算を実施する。同定結果の評価はこれら 1500 組の同 定計算結果の中央值と, すべての同定パラメターが真値の $\pm 5 \%, \pm$ $1 \%$ 範囲に収束する収束確率で評価する。同定計算結果の一覧を表 8 に示す。

表 8 より, 推定されたパラメターは SNR が大きくなるほじ中央值 のずれがやや大きくなるが，概补相対誤差 $1 \%$ 以内に収束しており， 同定精度に対するノイズの影響はそれほど大きくないことがわかる。 また収束確率の観点から評価すると, 真值に対して $5 \%$ 以内の範囲 で収束する確率は SNR が大きいほど高くなるが，真值に対して $1 \%$ 以内と高精度に同定する確率は SNR が小さいほど高くなる。特に SNR が $5 \%$ の場合には, 真值に対して $1 \%$ 以内に収束する確率はゼロ であった。このことから, 精度の高い同定結果を得るためにはでき るだけ SNR の小さい観測データを得る必要があり, SNR が $0.1 \%$ 程 度であれば概ね精度の良い推定が可能であると考えられる。

\section{5.まとめ}

既存木造住宅の現状の耐震性を評価し, より精度の高い耐震診断 や補強設計を行うことを目的として, 可変剛性を有する 1 自由度系 からなる可変振り子センサを設置して加振実験を行うことで, 対象 建物の質量を含めた物理的パラメターを推定する手法を考案した。

さらに，2 層せん断モデルと 1 層ねじれモデルを対象とする同定 シミュレーションを実施し, 建物質量の概水 1/1000 程度の振り子 質量を持つ可変振り子センサを用いて加振実験を行えば, 質量, 剛 性および粘性減衰係数といった物理的パラメターを同時推定可能で あることを示した。

2 層せん断モデルを用いた同定シミュレーション結果より, 可変 振り子センサの基準固有周期は対象建物の最高次モードの固有周期 程度に設定すると推定精度, 収束確率とも高い值を示し, 混入誤差 の SNR が $1 \%$ であれば, 推定誤差は最大 $5 \%$, 平均 $1 \%$ 以内の精度 で同定が可能であることが明らかとなった。また 1 層対じれモデル の場合には, 推定されたパラメターは SNR が大きくなるほど中央値 のずれがやや大きくなるが，概ね相対誤差 $1 \%$ 以内に収束しており， 同定計算結果に対するノイズの影響はそれほど大きくないとの結果 が得られた。

\section{謝辞}

本研究は「耐震実験施設の効率的運用による東海地域の地震災害 軽減連携融合事業」および前田記念工学振興財団の研究助成を受け た。また, 本研究に関わる数值計算等は三宅亮輔氏（当時名古屋大 学学部生）の協力を得た。ここに記して謝意を表す。

\section{参考文献}

1）今岡克也・佐伯圭彦・城殿準一郎：木造 2 階建住宅の耐震補強前後の震 動特性に関する研究 その $1 \sim 3$, 日本建築学会大会学術講演梗概集 (近畿),

C-1 構造III, pp. 125-130，2005.9

2) 年縄 巧: 起震器を用いた木造構造物の振動特性の評価, 日本建築学会 大会学術講演梗概集 (関東)， C-1 構造III，pp. 275-276，2006.9
3） 木曽久美子・渡辺千明・森井雄史・更谷安紀子・林康裕：三重県沿岸地 域における地域型木造住宅の地震被害低減策に関する研究 その 2 木造 住宅の耐震補強策の提案, 日本建築学会大会学術講演梗概集 (関東)，B-2 構造 II ，pp. 381-382，2006.9

4）曽根 彰・山本鎮男・増田 新：入出力のウエーブレット変換を用いた 多自由度系のパラメトリックなシステム同定，日本建築学会構造系論文集 第 512 号，pp. 61-66，1998. 10

5）中村 充・竹脇 出・安井 譲・上谷宏二：限定された地震観測記録を 用いた建築物の剛性と減衰の同時推定, 日本建築学会構造系論文集 第 528 号, pp. 75-82，2000.2

6）森 洋人・川瀬 博 : 確定付加質量がもたらす共振振動数の変動に基づ < $\mathrm{RC}$ 造建物の実質量と実剛性の同時推定，日本建築学会構造系論文集 第 559 号, pp. 93-100, 2002.9

7）川瀬 博・森 洋人・包那仁満都拉 : 質量変化に伴う振動数変化に基つ いた微少振幅時の免震層の剛性推定, 日本建築学会構造系論文集 第 590 号, pp. 37-44, 2005.4

8）栗原嵩明・水野啓示朗・古川忠稔：可変振り子センサを用いた質量・岡 性・減衰係数の同時推定方法 -1 自由度モデルによる同定シミュレーシ ヨン一, 日本建築学会大会学術講演梗概集 (関東), B-2 構造 II , pp. 163-164, 2006. 9

9）三宅亮輔・古川忠稔：可変振り子センサを用いた既存建築物動特性の推 定方法 -2 自由度系への適用一, 日本建築学会大会学術講演梗概集（九 州），構造 C-1, pp. 257-258, 2007.8

10) Ljung, L."System Identification Theory for the User Second Edition", Prentice Hall, 1999

11）古川忠稔・橘英三郎・井上 豊 : 予測誤差法による構造物の動的非線形特 性の推定 一バイリニア多層系せん断モデルの同定一, 構造工学論文集 Vol. 44B, pp. 375-384, 1998. 3

13）古川忠稔・伊藤雅史・小野聡子・橘英三郎：実地震観測記録を用いた 2 棟の免震建物動特性の同定, 日本建築学会構造系論文集 第 558 号, pp. 117-124, 2002.8

14) Tadatoshi Furukawa, Masashi Ito, Kiyozi Izawa, Mohammad N. Noori: System Identification of Base-Isolated Building using Seismic Response Data, Journal of Engineering Mechanics, Vol. 131 No. 3, ASCE, pp.268-275, 2005.3

15）平井卓郎・宮澤健二・小松幸平: 木質構造, pp. 157-189, 東洋書店, 2004 （2008年 9 月10日原稿受理，2009年 3 月 4 日採用決定） 